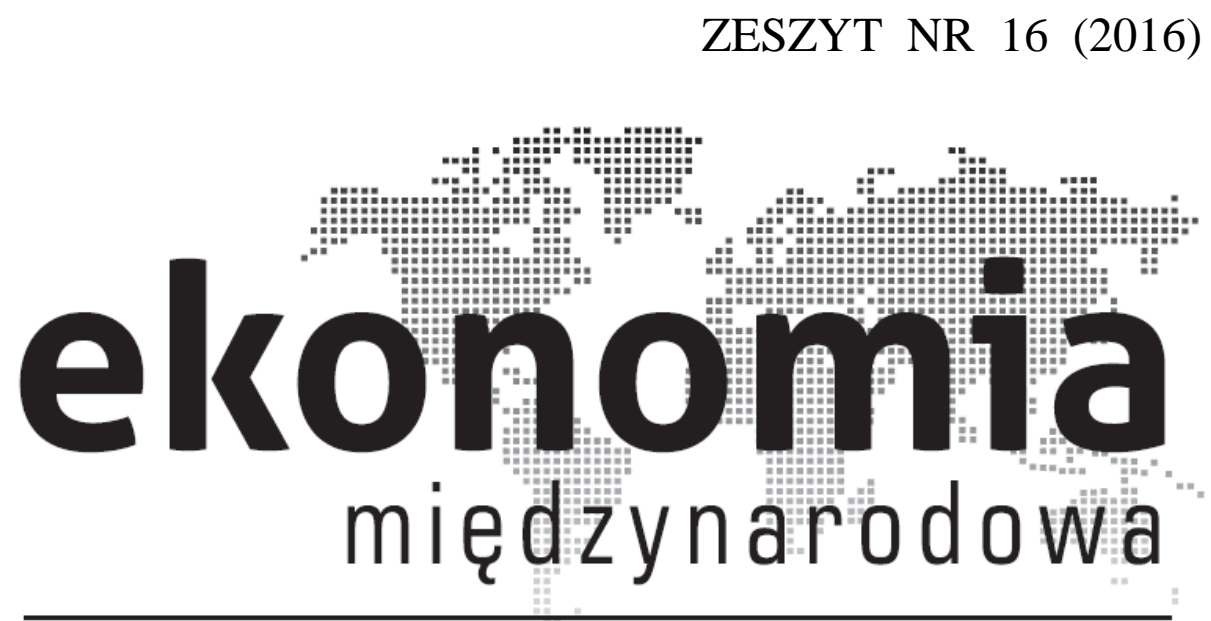

Ekonomia Międzynarodowa

Nr 16 (2016)

www.ekonomia-m.pl

ISSN: 2082-4440

EISSN: 2300-6005

Wydawca: Uniwersytet Łódzki

Wersja elektroniczna czasopisma jest wersją referencyjną
Publisher: University of Lodz

Electronic edition is the reference version of the journal
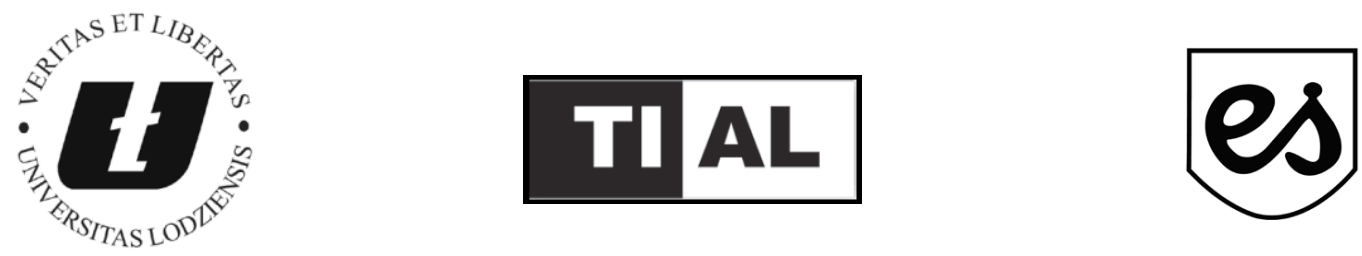


\section{Disclosure of risk information in the European banking sector}

Emilia Klepczarek*

\section{Introduction}

For the sake of the specific role that the banking sector plays in the economy (for a more theoretical background of the special role, see, for example: Bossone, 2000; Benston, 2004), strict disclosure requirements in relation to financial institutions are applied. The wide range of disclosures required by banking authorities is not only due to the interests of the stakeholders, but also the stability and security of the financial system.

The turbulences in the financial markets are a real threat to the entire economy because of the occurrence of the so-called contagion effect (for a detailed explanation of contagion see: Karolyi and Stulz, 1996). Therefore, it is important to introduce early warning systems based on the ongoing monitoring of the banking sector and to provide data analysis of the risks arising from the activities of banks and external conditions.

The proper functioning of early warning systems is subject to access to information about the various risks associated with the operations of financial institutions. Thus, the role of transparency and fulfilling the information requirements is often emphasized as the key issue in this sector. The relevance of disclosures was intensively discussed after the Global Financial Crisis, especially the risk and corporate governance data that appear to be essential when the banks' transparency is concerned. It is important to note that the quality and number of disclosures is directly related to the quality of corporate governance. This fact is emphasized, for example, by Bhimani (2009, pp. 2-5), Power (2009, pp. 849-855) and Harney (2010, pp. 14-17) in their research regarding risk accounting.

\footnotetext{
* Emilia Klepczarek - magister, Uniwersytet Łódzki, Wydział Ekonomiczno-Socjologiczny, Katedra Ekonomii Instytucjonalnej
} 
This paper examines the nature of risk disclosures of European banks with special consideration of the risks data required under International Financial Reporting Standards (IFRS) and local Generally Accepted Accounting Principles (GAAP). The article presents arguments supporting the importance of disclosures in the financial system. Various kinds of risks in the banking sector and the reporting requirements resulting from the application of different accounting standards will be characterized. Finally, the author will present the results of research based on data submitted by banks in accordance with the COREP standard, which is a technical reporting instrument designed to harmonize reporting in accordance with the Capital Requirements Directive (CRD).

\section{Risk disclosures literature review}

The risk disclosure research began with studies performed by the Institute of Chartered Accountants in England and Wales (ICAEW, 1997) and the Basel Committee on Banking Supervision (BCBS, 1998). They discussed the role of transparency and risk information that should be included in financial reports or other additional documents released by the companies. A theoretical debate, based on the BCBS survey, was presented by Linsley and Shrives (2005, pp. 205-214) who collated the risk disclosure requirements with banks' reporting practices.

Linsley and Shrives (2005, pp. 292-295) also conducted research which considered UK public companies listed on the FTSE 100. Their study found that, in most entities, risk disclosures are not quantitative but qualitative. A similar conclusion was reached by Lajili and Zeghal (2005, pp. 125-142), who analyzed 300 Canadian listed companies, stating that the usefulness of reported risk information is limited by the lack uniformity, clarity, and quantification. This is consistent with Woods, Dowd, and Humphrey's (2004) statement that the institutions "want to signal that they have state-of-the-art (or at least adequate) risk management systems, but they don't want to give real risk information away, as such information is commercially sensitive. Thus, 'risk disclosure' might be more apparent than real."

Presently, a great number of studies use disclosure indexes, which may be treated as important information about the quality of corporate governance practices. Their construction involves finding out whether specific company data is disclosed to the market.

The Brazilian Corporate Disclosure Index built by Lopes and de Alencar (2008) is based on the answers to 47 questions relating to general information about companies, their compensation policies, non-financial market data, sales, cash flow and earnings forecast, and the analysis of financial and other data. Cheung, Connely, and Limpaphayon (2007, pp. 313-342) used the information about disclosures for the construction of a disclosure index for Thailand and Hong Kong. It includes "poor/fair/excellent" answers regarding the disclosures of stakeholders' 
rights protection, equality of investors' treatment, the role of stakeholders in corporate governance practices, companies' transparency, and the role of boards of directors. Lopes and Rodrigues (2007, pp. 25-56) used the financial instruments disclosure index as a dependent variable trying to evaluate the disclosure determinants in Portugal. They analyzed 54 elements regarding the information on accountancy policy, fair and market values, securitization, derivatives, interest rate risk, credit risk, collaterals, and others. Cheung, Jiang, and Tan (2010, pp. 259-280) presented disclosure measures divided into obligatory and facultative ones in terms of the reporting practices of the largest publicity traded Chinese companies. A Polish Corporate Disclosure Index also exists (Świderska, 2010) which is a weighted average of disclosures taken from companies' financial statements (66\%), operating statements (24\%) and reports of relationships with the business environment (10\%).

\section{The importance of disclosures in financial statements}

The objective of financial statements is to provide information about the financial position, financial performance, and cash flows of an entity that could be useful to a wide range of market participants in making economic decisions (Świderska, 2010 , p. 15). In addition, it proves the managers' diligence in managing the resources entrusted to them, and it thereby reduces the information differences and conflicting incentives between entrepreneurs and savers (Healy, Palepu, 2001, p. 407).

Some aspects of the problem of asymmetric information may be solved with the high transparency of managers' decisions and activities ${ }^{1}$. The transparency and honesty of information is expected to be guaranteed by the capital markets intermediaries, such as financial analysts and rating agencies. Figure 1 provides a diagram of the flow of capital (left side) and the flow of information (right side) within the capital markets.

Figure 1. Information and capital flow in the capital markets

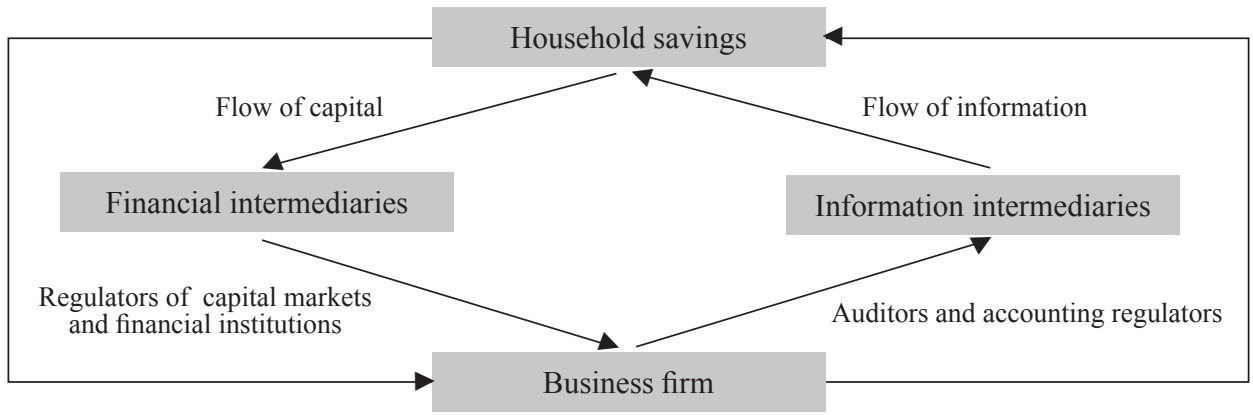

Source: Healy \& Palepu (2001, p. 407)

\footnotetext{
${ }^{1}$ Transparency, however, does not solve all the aspects of the problem of asymmetric information see for example the idea of 'lemon problem' (Akerlof, 1970).
} 
As is shown in Figure 1, the investor is not an identical entity to the entrepreneur. That implies the existence of the so-called agency problem, which is a result of the unbundling of ownership and management (a detailed explanation of the agency problem may be found in: Jensen and Meckling, 1976). Savers usually do not intend to engage in managing and delegating all the business decisions to their agents (managers) who are responsible for dealing properly with the entrusted capital. It may cause two major kinds of conflicts - insufficient motivation on the part of the managers to look for business opportunities, and the 'moral hazard', meaning the idea of putting managers' interests ahead of the company's.

One of the possible solutions available to reduce the agency problem is the disclosure policy which provides market participants with the adequate data that enable them to monitor and make decisions and take actions involving (Świderska, 2010, p. 15):

1) buying, maintaining, or selling securities,

2) assessing the efficiency of the management,

3) assessing the company's ability to pay wages and other employee benefits,

4) assessing the quality of collaterals and loans,

5) evaluating the tax policy,

6) determining the proportions of profit-sharing and dividends,

7) preparing statistical data regarding the GDP,

8) regulating the business activities.

\section{Types of risk in the banking sector}

The provision of financial services by banks implies the existence of various kinds of risk that should be carefully recognized and analyzed. Proper risk measurement and management seem to be the most important issues when the functioning of financial institution is concerned. Table 1 presents the risk characteristics specified by Santomero (1997), Pyle (1997) and Frendzel et al. (2011).

Table 1. Characterization of types of banking risk

\begin{tabular}{|l|l|l|l|}
\hline Type of risk & Santomero & Pyle & Frendzel et al. \\
\hline Market & See: systematic risk & $\begin{array}{l}\text { the change in net asset } \\
\text { value due to changes in } \\
\text { underlying economic } \\
\text { factors such as interest } \\
\text { rates, exchange rates, and } \\
\text { equity and commodity } \\
\text { prices }\end{array}$ & $\begin{array}{l}\text { The volatility of the fair } \\
\text { value of the financial in- } \\
\text { struments or future cash } \\
\text { flows due to changes of } \\
\text { the market prices }\end{array}$ \\
\hline Credit & $\begin{array}{l}\text { Risk arising from either } \\
\text { the inability or unwilling- } \\
\text { ness of a borrower to per- } \\
\text { form in the pre-arranged, } \\
\text { contracted manner }\end{array}$ & $\begin{array}{l}\text { The change in net asset } \\
\text { value due to changes the } \\
\text { perceived ability of coun- } \\
\text { terparties to meet their } \\
\text { contractual obligations }\end{array}$ & $\begin{array}{l}\text { The risk of loss result- } \\
\text { ing from the inability } \\
\text { to fulfill the contractual } \\
\text { obligations by the coun- } \\
\text { terparty }\end{array}$ \\
\hline
\end{tabular}




\begin{tabular}{|c|c|c|c|}
\hline Type of risk & Santomero & Pyle & Frendzel et al. \\
\hline Operational & $\begin{array}{l}\text { Risk associated with the } \\
\text { problems of accurately } \\
\text { processing, settling, and } \\
\text { taking or making de- } \\
\text { livery on trades in ex- } \\
\text { change for cash. It also } \\
\text { arises in record keeping, } \\
\text { processing system fail- } \\
\text { ures, and compliance } \\
\text { with various regulations }\end{array}$ & $\begin{array}{l}\text { Risk resulting from } \\
\text { costs incurred through } \\
\text { mistakes made in carry- } \\
\text { ing out transactions such } \\
\text { as settlement failures, } \\
\text { failures to meet regula- } \\
\text { tory requirements, and } \\
\text { untimely collections }\end{array}$ & - \\
\hline $\begin{array}{l}\text { Perfor- } \\
\text { mance }\end{array}$ & - & $\begin{array}{l}\text { Risk encompassing } \\
\text { losses resulting from } \\
\text { the failure to properly } \\
\text { monitor employees or to } \\
\text { use appropriate methods } \\
\text { (including "model risk"). }\end{array}$ & - \\
\hline Systematic & $\begin{array}{l}\text { The risk of asset value } \\
\text { change associated with } \\
\text { systematic factors. It is } \\
\text { sometimes referred to as } \\
\text { market risk }\end{array}$ & - & - \\
\hline $\begin{array}{l}\text { Coun- } \\
\text { terparty }\end{array}$ & $\begin{array}{l}\text { Risk coming from the } \\
\text { non-performance of a } \\
\text { trading partner. The non- } \\
\text { performance may arise } \\
\text { from a counterparty's } \\
\text { refusal to perform due to } \\
\text { an adverse price move- } \\
\text { ment caused by sys- } \\
\text { tematic factors, or from } \\
\text { some other political or } \\
\text { legal constraint that was } \\
\text { not anticipated by the } \\
\text { principals }\end{array}$ & - & - \\
\hline Liquidity & $\begin{array}{l}\text { The risk of a funding } \\
\text { crisis }\end{array}$ & - & $\begin{array}{l}\text { The risk of the inability } \\
\text { of the bank to fulfill its } \\
\text { obligations }\end{array}$ \\
\hline Legal & $\begin{array}{l}\text { Risk endemic in finan- } \\
\text { cial contracting and } \\
\text { separate from the legal } \\
\text { ramifications of credit, } \\
\text { counterparty, and opera- } \\
\text { tional risks. These are } \\
\text { new statutes, tax legisla- } \\
\text { tion, court opinions and } \\
\text { regulations as well as } \\
\text { fraud, violations of regu- } \\
\text { lations or laws }\end{array}$ & - & - \\
\hline
\end{tabular}

Source: author's own elaboration. 
Table 1 shows that there is no universal specification of the types of risk in the banking sector. This is not only because of the terminology, as seems to be the case with market and systematic risk in Santomero's study. Some authors aggregate various kinds of risks in one category or they simply ignore some factors, regarding them as unknowns with no measurable probability of outcome ${ }^{2}$.

Most of the above-mentioned risks could be recognized and properly managed only on condition that the corporate governance processes are well-defined and implemented. They guarantee the transparency of banking operations and mitigate the agency conflict, which could lead to underestimating or hiding the risk to stakeholders in order to enable some morally hazardous actions. It should be noted, however, that several kinds of risk are hard or even impossible to predict and measure. These are, for example systematic, counterparty and legal risks which mostly depend on external circumstances. The other risk factors are usually identifiable if two preconditions exist - the high level of transparency and proper measurement.

\section{Disclosure requirements according to GAAP and IFRS}

In the late 1990s, companies in several EU member states were allowed to voluntarily apply International Financial Reporting Standards rather than local Generally Accepted Accounting Principles. Presently, however, after 1st January 2005, the International Accounting Standards (IAS) regulation requires publicly traded companies to present consolidated financial statements in conformity with IFRS adopted by the European Union (IFRS-EU) for each financial year. Member states may permit companies to defer the application of IFRS-EU when:

1) only their debt securities are admitted to trading on a regulated market of any member state; or

2) their securities are admitted to public trading in a non-member state and, for that purpose, they have been using internationally accepted standards since a financial year that started prior to 11 September 2002 (for this purpose, internationally accepted standards are generally understood to include only US GAAP).

In practice, the IAS Regulation allows jurisdictions to prohibit any specific type of company from using IFRS in their legal entity financial statements, and, in the case of non-publicly traded companies, their consolidated financial statements (Financial Reporting Faculty, 2007, p. 19). Thus, only some European countries apply IFRS to all bank entities, while most of them allow both IFRS and local GAAP regulations to be used (see: Figure 2).

\footnotetext{
${ }^{2}$ Risk is usually defined as an unknown with measurable probabilities. An unknown with no measurable probability is uncertainty
} 
Figure 2. The accountancy standards requirements (European banks)

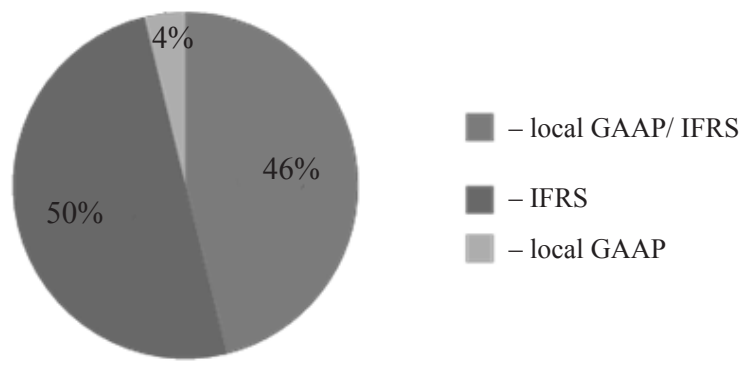

Source: own calculations based on COREP statistics.

According to IFRS 7 - the standard relating to financial instruments disclosures - entities should disclose both qualitative and quantitative data concerning the market risk, credit risk, and liquidity risk (see: Figure 3). The objective of IFRS 7 is "to require entities to provide disclosures in their financial statements, that enable users to evaluate (1) the significance of financial instruments for the entity's financial position and performance; and (2) the nature and extent of risks arising from financial instruments to which the entity is exposed during the period and at the reporting date, and how the entity manages those risks" (International Accounting Standards Board, 2009).

Figure 3. IFRS 7 Risk Framework

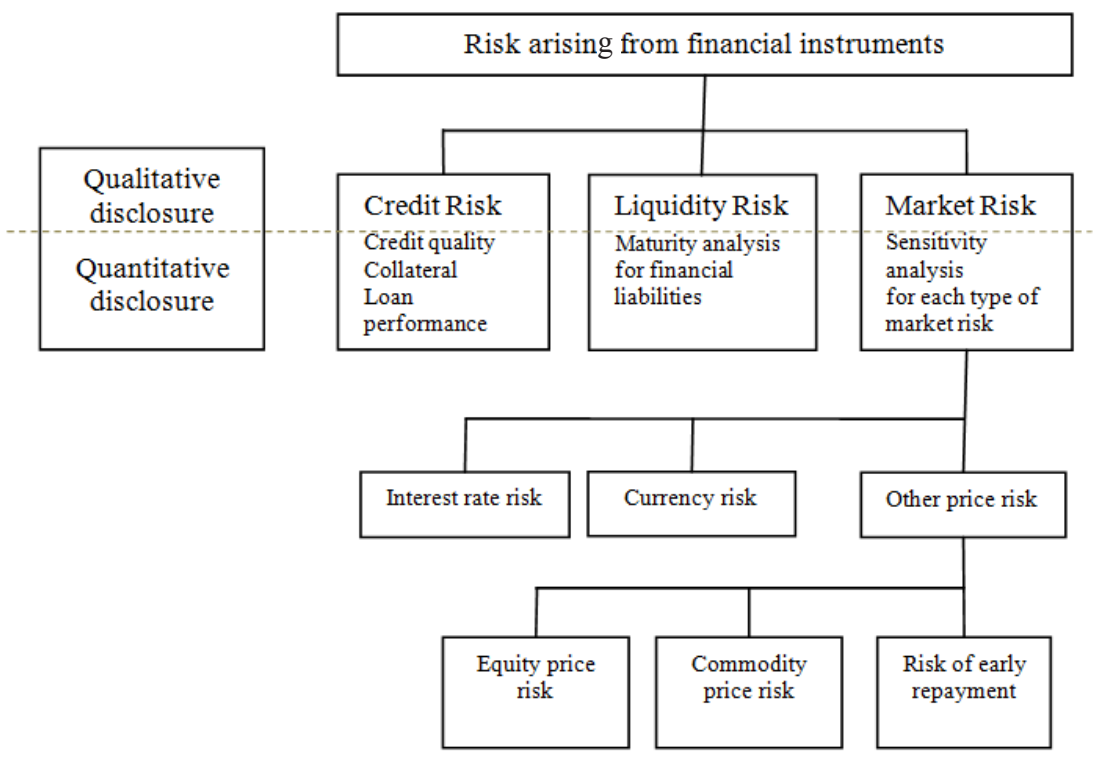

Source: Redaelli (2007). 
IFRS 7 requires information including complex but not too highly aggregated data about the risk factors. The risk report may be a part of the financial statement, another business report, or it may be published as a separate document. European financial institutions deliver the risk data using COREP and FINREP reports which are standardized formats provided by European Banking Authorities (EBA) in XBRL (Extendable Business Reporting Language).

Local GAAP regulations are not standardized with regard to risk disclosure requirements. In particular, they do not include the obligation to literally specify the various kinds of risk, as is the case with IFRS. The US GAAP standards, for example, concentrate more on fair value disclosures and require a higher level of transparency of valuation techniques and inputs used to measure fair value (PricewaterhouseCoopers, 2011, p. 61). It should be mentioned, however, that calculating the fair value requires elements concerning, among others, the credit risk, market risk, off-balance sheet risk, significant estimates, and their uncertainty.

By contrast, the NL GAAP standards do not have a fair value option. They invoke the previous requirements of IAS 32 that established principles for presenting financial instruments as liabilities or equity and for offsetting financial assets and liabilities (International Accounting Standard 32). But, as with the US GAAP, there is no demand to disclose the exact level of specific risks.

Although the local GAAP allow entities not to cautiously define the specific risk types, the COREP standard, which has been mandated by the Committee of Banking Supervision (CEBS) as an obligatory format since 2014, includes detailed disclosures regarding credit, market, and operational risk. A complete set of COREP risk disclosures is presented in Table 2.

Table 2. Types of risk disclosures included in the COREP template

\begin{tabular}{|l|l|l|}
\hline Credit Risk & Market Risk & Operational Risk \\
\hline $\begin{array}{l}\text { Credit and counterparty credit } \\
\text { risks and free deliveries: Stand- } \\
\text { ardised Approach to Capital } \\
\text { Requirements }\end{array}$ & $\begin{array}{l}\text { Market Risk: Standardised } \\
\text { Approach for Position Risks } \\
\text { in Traded Debt Instruments }\end{array}$ & Operational Risk \\
\hline $\begin{array}{l}\text { Credit and counterparty credit } \\
\text { risks and free deliveries: In- } \\
\text { ternal Rating Based Approach } \\
\text { to Capital Requirements }\end{array}$ & $\begin{array}{l}\text { Market Risk: Standardised } \\
\text { Approach for Position Risks } \\
\text { in Equities }\end{array}$ & $\begin{array}{l}\text { Operational Risk: Gross } \\
\text { Losses by Business Lines and } \\
\text { Event Types in the last year }\end{array}$ \\
\hline $\begin{array}{l}\text { Credit risk: Equity: Internal } \\
\text { Rating Based Approaches to } \\
\text { Capital Requirements }\end{array}$ & $\begin{array}{l}\text { Market Risk: Standardised } \\
\text { Exproaches for Foreign }\end{array}$ & $\begin{array}{l}\text { Losses recorded in the } \\
\text { last year or which are } \\
\text { still open }\end{array}$ \\
\hline
\end{tabular}




\begin{tabular}{|l|l|l|}
\hline $\begin{array}{l}\text { Credit risk: Securitisation: } \\
\text { Standardised Approach to } \\
\text { Capital Requirements }\end{array}$ & $\begin{array}{l}\text { Market Risk: Standardised } \\
\text { Approaches for Commodities }\end{array}$ & \\
\hline $\begin{array}{l}\text { Credit risk: Securitisation: In- } \\
\text { ternal Rating Based Approach } \\
\text { to Capital Requirements }\end{array}$ & Market Risk: Internal model & \\
\hline $\begin{array}{l}\text { Credit risk: Detailed infor- } \\
\text { mation on securitisations by } \\
\text { originators and sponsors }\end{array}$ & $\begin{array}{l}\text { Market Risk Internal Model } \\
\text { Details }\end{array}$ & \\
\hline $\begin{array}{l}\text { Settlement/Delivery Risk in } \\
\text { the Trading Book }\end{array}$ & & \\
\hline
\end{tabular}

Source: European Banking Authority.

Using the COREP template doesn't mean that all entities report every piece of information listed in Table 2, however. Some of them are fully reported, some are reported partially, and some are not disclosed for various reasons. For example, if one considers the Standardized Approach and Internal Rating Based Approach measures, it should be noted that they do not always need to be calculated using both methods. In the standard method, banks use the regulatory risk weight coefficient, which is based on the quality of the loan quantified by external ratings. The IRB method assumes that the bank is able to calculate the risk using the internal models instead of relying on the outside rating agency.

\section{Methodology of the research}

The aim of the study is to find out if the amount of disclosed risk data depends on the applied accountancy standards. The author will also check whether more stable bank sectors tend to disclose a wider scope of risk information.

The database which is the subject of the analysis has been developed on the basis of information published on the website of the European Banking Authority (EBA) and data from the SNL Financial database. It includes aggregated information on 30 European banking markets regarding the range of disclosures of the capital adequacy, values of their own funds established for the purposes of calculating the capital adequacy ratio, capital requirements for particular risks, and data on the values of exposure subject to various risks, taking into account the risk mitigation methods.

The database has been supplemented with qualitative variables, i.e. the value of risk-weighted assets (RWA) and capital adequacy ratios (CAR) of each country capital sector (aggregated data). Asset value usually determines the size of the 
banking sector, while CAR may be considered a measure of banking system stability $^{3}$ (for more about bank stability measures see: Capiga, 2010; Capiga et al., 2011).

The influence of accounting standards on the number of disclosures was assessed with variance analysis (Welch and Brown-Forsythe tests). To simplify the calculation, the author constructed the disclosure index and confirmed its reliability with Cronbach's alpha coefficient. Linear regression analysis was also used to check if the scope of the disclosures depends on the bank sector stability.

\section{Data and statistics}

Common statistics for the capital adequacy ratio are presented in Table 3. The results show that in European banks, the average of CAR was $12.4 \%{ }^{4}$, and the value of risk-weighted assets coverage deviates from the mean average by 3.7 percent points. There is quite a large gap between the minimum $(0.56 \%)$ and maximum $(18.49 \%)$ level of CAR. Distribution is skewed left, thus, it should be assumed that more countries have a higher than average rate. Kurtosis is positive, which leads to the conclusion that more observations are concentrated around the center of the distribution.

Table 3. Common statistics for the capital adequacy ratio (CAR)

\begin{tabular}{|l|c|c|}
\hline Descriptive & Value & St. error \\
\hline mean & 12.39 & 0.81 \\
\hline median & 12.89 & \\
\hline variance & 13.73 & \\
\hline standard deviation & 3.71 & \\
\hline minimum & 0.56 & 0.50 \\
\hline maximum & 18.49 & 0.97 \\
\hline skewness & -1.45 & \\
\hline kurtosis & 4.38 & \\
\hline
\end{tabular}

Source: author's own elaboration based on SNL Financial Database.

\footnotetext{
${ }^{3}$ Studies can be found which use regression models with a credit-to-GDP gap as the dependent variable measuring financial stability (see: Detken et al., 2014). However, credit-to-GDP indicates the stability of the country's financial system, while CAR indicates the stability of financial institutions, which is not exactly the same, in the author's opinion.

${ }^{4}$ CAR (Capital adequacy ratio) is the ratio of a bank's capital to its risk-weighted assets.
} 
Taking into account the aim of the study, which is to find out if the accounting standards influence the number of disclosures, the variance analysis will be conducted. It allows us to examine whether countries using different accounting standards differ greatly in terms of risk disclosures.

The variable "accounting standards" was simplified by giving it two values: 0 - meaning countries in which both national and international standards are used, and 1 - meaning countries where only international standards are required. To create a variable aggregating disclosure range on all areas listed in the database (a kind of risk disclosure index), "disc_..." variables were set up, which take a value of 1 for those categories which are disclosed and 0 in other cases (partially disclosed or non-disclosed). A new variable, "discl.index", was then created, which is the sum of the above discrete variables and indicates how much information the individual countries disclose in the reports sent to the European Banking Authority.

For the evaluation of the reliability of the constructed index, Cronbach's alpha coefficient was used. It gives information about the degree to which a set of variables describes one construct hidden within them. It can also be interpreted as a measure of the internal consistency of the scale. Cronbach's alpha coefficient falls within the range between 0 and 1 . The high reliability of the scale is indicated by values greater than 0.7 , but a scale for which Cronbach Alpha $>0.6$ is considered acceptable.

In the case of the sum of the variables concerning disclosures (discl.index), Cronbach's alpha coefficient is 0.94 , which indicates the high reliability of the scale and confirms that the index constructed on the basis of the above data describes the scope of disclosures relatively well. The removal of certain items would give only a very slight improvement in the coefficient.

The next step is to check the assumptions of the normal distribution and homogeneity of the variance of the studied variables (accounting standards and disclosure index). The results are presented in the Table 5.

Table 5. Tests for the normality of distributions (Shapiro-Wilk)

\begin{tabular}{|l|c|c|c|}
\hline Variable & Statistic & df & Sig. \\
\hline IFRS & 0.932 & 6 & 0.598 \\
\hline local GAAP/IFRS & 0.933 & 12 & 0.413 \\
\hline discl.index & 0.833 & 5 & 0.147 \\
\hline
\end{tabular}

Source: author's own elaboration based on COREP template of European Banking Authority

The research uses the Shapiro-Wilk Test, wherein:

$\mathrm{H}_{0}$ : the dependent variable has a normal distribution

$\mathrm{H}_{1}: \sim \mathrm{H}_{0}$ 
In the Shapiro-Wilk tests, the sig. value is greater than the significance level of 0.05 , so the variables can be regarded as normally distributed.

Then Levene's Test for Equality of Variances can be used, which verifies the assumption of the homogeneity of the variance of the dependent variable within a subpopulation. The hypothesis that the variances of disclosure index are homogeneous is considered to be met if Levene's test $p>0.05$. In this case $p=0.032$, thus one has to reject the assumption of homogeneity of variance.

If this assumption turns out to be broken, the Brown-Forsythe and Welch options will display alternative versions of the $\mathrm{F}$ statistic, which means it can be still verified if there is a difference in the mean of the disclosure index within the two subpopulations (divided by taking into account the accounting standards requirements). Table 6 shows the results of the Brown-Forsythe and Welch tests.

Table 6. Robust Tests of Equality of Means

\begin{tabular}{|l|c|c|c|c|}
\cline { 2 - 5 } \multicolumn{1}{c|}{} & Statistics & df1 & df2 & Sig. \\
\hline Welch & 0.000 & 1 & 18.067 & 0.992 \\
\hline Brown-Forsythe & 0.000 & 1 & 18.067 & 0.992 \\
\hline
\end{tabular}

Source: author's own elaboration based on COREP template of European Banking Authority

For the above tests, the hypotheses take the form of:

$\mathrm{H}_{0}$ : average in the populations are equal

$\mathrm{H}_{1}: \sim \mathrm{H}_{0}$

In both the Welch and the Brown-Forsythe tests, the significance is at a level of 0.992 ( $p>0.05)$. Thus, one can accept $\mathrm{H}_{0}$ and assume that the two independent groups come from populations with the same distribution. Therefore, the accounting standards do not differentiate the scope of disclosures.

It may be also checked whether the scope of the disclosure of information depends on the bank sector stability. In other words, it is an attempt to find an answer to the question whether more stable banking systems are more likely/more demanding in terms of information requirements.

To verify the above-mentioned statement, linear regression analysis is used. Tables 7 and 8 present the output of the regression coefficients estimations. The results indicate a very weak positive correlation $(\mathrm{R}=0.11)$. The variability of the disclosure index is explained with a CAR of only $0.012 \%$, which means that the model fits the data poorly. The values in the Sig. column for both variables are above 0.05 . Therefore, there is no evidence to reject the null hypothesis which states that the impact of the variable is not significant. It must be assumed that the CAR variable does not significantly affect the disclosure index. 
Table 7. Model summary

\begin{tabular}{|c|c|c|c|}
\hline $\mathrm{R}$ & R-square & Adjusted R-square & St. error of the estimate \\
\hline $0.108^{\mathrm{a}}$ & 0.012 & -0.043 & 5.95036 \\
\hline
\end{tabular}

Predictors: (Constant), CAR.

Source: author's own elaboration based on COREP template of European Banking Authority and SNL financial Database.

Table 8. Coefficients, dependent variable: disclosure index

\begin{tabular}{|l|c|c|c|c|c|}
\cline { 2 - 4 } \multicolumn{1}{c|}{} & \multicolumn{2}{c|}{ Unstandardized coefficients } & Standardized coef. & \multirow{2}{*}{ t } & \multirow{2}{*}{ Sig. } \\
\cline { 2 - 4 } \multicolumn{1}{c|}{} & B & St. Error & Beta & & \\
\hline $\begin{array}{l}\text { (Constant) } \\
\text { CAR }\end{array}$ & 12.543 & 6.968 & & 1.800 & 0.089 \\
\cline { 2 - 6 } & -0.242 & 0.527 & -0.108 & -0.460 & 0.651 \\
\hline
\end{tabular}

Source: author's own elaboration based on COREP template of European Banking Authority and SNL financial Database.

Summarizing, on the basis of the tests presented, we can conclude that the selected countries do not differ from each other in terms of disclosed data according to accounting standards. Also, the level of their solvency measured by the capital adequacy ratio does not affect the level of transparency.

Thus, for the purposes of identifying factors affecting transparency in the banking sector, one should focus on the analysis of the legal regimes of individual countries which belong to the transnational financial safety net organizations, as well as historical and cultural factors related to the transparency of economic activity, particularly in the area of financial markets.

\section{Conclusions}

The Basel Committee on Banking Supervision defines transparency as 'the public disclosure of reliable and timely information that enables users of that information to make an accurate assessment of a bank's financial condition and performance, business profile, risk profile and risk management. This definition recognizes that disclosure alone does not necessarily result in transparency' (Basel Committee on Banking Supervision, 1998, p. 4).

That is a crucial statement where the above presented results are concerned. It should be emphasized that, although accounting standards do not differentiate the amount of disclosed data, they may affect the quality of the information given to the public. It seems then that the debate on risk disclosures should concentrate not on their scope, which is quite standardized, but on the credibility of the data. 
The information put in the public domain should be reliable so as to fulfill the function of mitigating the information asymmetry problem. The Global Financial Crisis proved that the quality of information - both given directly by banks and by market intermediaries, such as credit rating agencies - is poor and misleading. If the data credibility is provided, then the authorities may concern themselves with the problem of the scope of disclosures.

There are several arguments for increasing the amount of released information (Linsley, Shrives, 2005, p. 206). Firstly, the relevant information about the risk policy and management enables the market participants to sanction banks with an unsatisfactory risk profile. On the other hand, well managed banks may benefit by decreasing their cost of finance, due to the greater confidence of the investors. Secondly, the requirement of disclosing the risk level obliges managers to work out adequate early warning systems which may be useful not only to estimate the level of presently undertaken risk, but also to predict some threats and plan prudential procedures. Eventually, competition within the banking sector forces the banks to fight for the trust of depositaries, stockholders, investors, and contractors. The specific role of the financial institutions means that they earn trust not only with the increasing profitability but also with a better prudential policy. If they are required to disclose this kind of information, they would probably improve the risk management to enhance their economic standing and competitiveness.

Taking all these arguments into account, it seems essential to care about the scope of risk disclosures and find the determinants of the amount of disclosed data. The presented study proves that, as far as the European banking sector is concern, it does not depend on accountancy standards, nor on the stability of the sector (if it is measured with the capital adequacy ratio). It is therefore necessary to review the other determinants of disclosures (regulatory agency requirements for financial markets, the degree of development/market size, etc.). At the same time, it should be remembered that prerequisites of transparency include not only the great amount of disclosed information but also: the timeliness, comprehensiveness, reliability, relevance, comparability, and materiality of the reported datasets (Linsley, Shrives, 2005, p. 206).

\section{References}

Akerlof, G. (1970), The market for lemons: Quality uncertainty and the market mechanism, "Quarterly Journal of Economics", Vol. 84, s. 488-500.

Basel Committee on Banking Supervision (1998), Enhancing Bank Transparency Public disclosure and supervisory information that promote safety and soundness in banking systems, Bank for International Settlements, Bazylea.

Benston, G.J. (2004), What's Special About Banks?, "Financial Review", Vol. 39, No. 1, s. 13-33. 
Bhimani, A. (2009), Risk management, corporate governance and management accounting: Emerging interdependencies, "Management Accounting Research", Vol. 20, No. 1, s. 2-5.

Bossone, B. (2000), What Makes Banks Special? A Study of Banking, Finance, and Economic Development, Policy Research Working Paper; No. 2408. World Bank, Washington, DC.

Capiga, M. (2010), Zarządzanie bankiem, PWN, Warszawa.

Capiga M., Gradoń W., Szustak G. (2011), Adekwatność kapitałowa w ocenia bezpieczeństwa banku, CeDeWu, Warszawa.

Cheung, S.Y.-L., Connely, J. T., Limpaphayon, P. (2007). Determinants of corporate disclosure and transparency: Evidence from Hong Kong and Thailand, "International Corporate Responsibility Series", Vol.3, s. 313-342.

Cheung, S.Y.-L., Jiang, P., Tan, W. (2010), A transparency Disclosure index measuring disclosures: Chinese listed companies, "Journal of Accounting and Public Policy", Vol. 29, No. 3, s. 259-280.

Detken C., Weeken, O., Alessi, L., Bonfim, D., Boucinha, M.M., Castro, C., Frontczak, S., Giordana, G., Giese, J., Jahn, N., Kakes, J., Klaus, B., Lang, J. H., Puzanova, N., Welz, P. (2014), Operationalizing the Countercyclical Capital Buffer, ESRB Occasional Paper, No. 5, Frankfurt nad Menem.

Financial Reporting Faculty (2007), EU Implementation of IFRS and the Fair Value Directive. A report for the European Commission, The Institute of Chartered Accountants in England and Wales, Londyn.

Frendzel, M., Ignatowski, R., Kabalski, P. (2011), Ujawnienia w sprawozdaniach finansowych. MSR 1, MSSF 7, MSSF 8, Stowarzyszenie Księgowych w Polsce, Warszawa.

Harney, S. (2010), Accounting risk and revolution, "Critical Perspective on Accounting", Vol. 21, No. 1, s. 14-17.

Healy, P.M., Palepu, K.G. (2001), Information asymmetry, corporate disclosure, and the capital markets: A review of the empirical disclosure literature, "Journal of Accounting and Economics", Vol. 31, No. 1-3, s. 405-440.

Institute of Chartered Accountants in England and Wales (1997), Financial reporting of risk- proposals for a statement of business risk, ICAEW Financial Reporting Committee, London.

International Accounting Standards Board (2009), Technical Summary: IFRS 7 Financial Instruments: Disclosures, www.iasb.org.

Jensen, M.C., Meckling W.H. (1976), Theory of the firm: managerial behavior, agency costs and ownership structure, "Journal of Financial Economics", Vol. 3, s. 305-360.

Karolyi, G.A., Stulz R.M. (1996), Why Do Markets Move Together? An Investigation of U.S.-Japan Stock Return Comovements, "The Journal of Finance", Vol. 51, No. 3, s. 951-986. 
Lajili, K., Zéghal, D. (2005), A Content Analysis of Risk Management Disclosures in Canadian Annual Reports, "Canadian Journal of Administrative Sciences", Vol. 22, No. 2, s. 125-142.

Linsley, P.M., Shrives, P.J. (2005), Examining Risk Reporting in UK Public Companies, "Journal of Risk Finance", Vol. 6, No. 4, s. 292-305.

Linsley, P.M., Shrives, P.J. (2005), Transparency and the Disclosure of Risk Information in the Banking Sector, "Journal of Financial Regulation and Compliance", Vol. 13, No. 3.

Lopes, P.T., Rodrigues, L.L. (2007), Accounting for financial instruments: An analysis of the determinants of disclosure in the Portuguese stock exchange, "The International Journal of Accounting", Vol. 42, No. 1, s. 25-56.

Lopes, A.B., de Alencar, R.C. (2008), Disclosure and cost of equity capital in the emerging markets: the Brazilian Case, "SSRN Electronic Journal", Vol. 45, No. 4, s. 443-464.

Power, M. (2009), The risk management of nothing, "Accounting, Organizations and Society", Vol. 34, No. 6-7, s. 849-855.

PricewaterhouseCoopers. (2011), Similarities \& differences. A comparison of US GAAP and IFRS for investment companies, Nowy Jork, NY.

Pyle, D.H. (1997), Bank Risk Management: Theory, Working Paper, Haas School of Business, University of California, Berkeley.

Redaelli, L. (2007), La prima applicazione del principio contabile IFRS 7, PWC Conference Proceedings, Mediolan.

Santomero, A.M. (1997), Commercial Bank Risk Management: An Analysis of the Process, Paper presented at the Wharton Financial Institutions Center Conference on Risk Management in Banking (October 1996), University of Pennsylvania, Filadelfia.

Świderska, G.K., red. (2010), Wplyw zakresu ujawnianych informacji na poprawe ochrony inwestorów oraz pozycję konkurencyjna papierów wartościowych, Szkoła Główna Handlowa, Warszawa.

Woods, M., Dowd, K., Humphrey, C.G. (2004), Credibility at Risk? The Accounting Profession, Risk Reporting and the Rise of VaR, CRIS Discussion Paper Series 2004.III, Nottingham.

\section{Summary}

A debate on the scope of bank information disclosures seems to be essential, especially after the Global Financial Crisis. The adequate quantity of data provided to the public domain is a condition of transparency of the banking sector which should assure the optimization of market participants' decisions. There is also a tendency to unify global accountancy standards, and they are expected to ensure the same scope of disclosed information for the global financial market. The aim 
of the study is to investigate if there are any differences with the number of risk disclosures among the banks using GAAP and IFRS accounting standards, and if more stable banking sectors tend to report a wider scope of data. Finding out the nature of the determinants of disclosures is an important aspect in terms of working out the procedures which will increase the transparency and stability of the financial markets.

Keywords: risk disclosures, financial statements, accounting standards, GAAP, IFRS

\section{Streszczenie}

\section{Zakres informacji o ryzyku ujawnianych w podmiotach europejskiego sektora bankowego}

Doświadczenia globalnego kryzysu finansowego sprawiły, że debata nad zakresem informacji ujawnianych przez banki nabrała szczególnego znaczenia. Odpowiednia ilość danych trafiających do domeny publicznej warunkuje bowiem przejrzystość sektora bankowego optymalizującą decyzje uczestników rynku. Jednocześnie na globalnym rynku finansowym obserwuje się tendencję do ujednolicania standardów rachunkowości, aby zakres ujawnianych informacji był taki sam. Celem przedstawionych w artykule badań jest zweryfikowanie istnienia różnic, jeśli chodzi o ilość ujawnianych informacji wymaganych standardami GAAP i IFRS, oraz zbadanie, czy bardziej stabilne sektory bankowe mają tendencję do ujawniania większego zakresu danych. Wskazanie czynników determinujących poziom ujawnień wydaje się istotne dla wypracowania procedur poprawiających przejrzystość i stabilność rynków finansowych.

Słowa kluczowe: ujawnienia ryzyka; sprawozdania finansowe; standardy rachunkowości; GAAP; IFRS

JEL: E44, E52, E58, F33, G18, G21, G28 